\title{
ОЦЕНКА ЭФФЕКТИВНОСТИ ПРИМЕНЕНИЯ ПОЛИМЕРНОГО ЗАВОДНЕНИЯ ДЛЯ ПОВЫШЕНИЯ НЕФТЕОТДАЧИ ПЛАСТОВ В УСЛОВИЯХ ПОЗДНЕЙ СТАДИИ РАЗРАБОТКИ
}

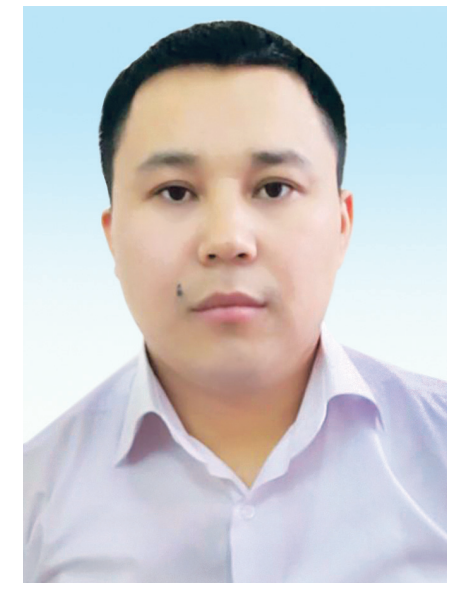

\author{
М.Е. КАЛИ, \\ доктор PhD, \\ по экономике, эксперт по \\ экономическим исследованиям, \\ https://orcid.org/ 0000-0002- \\ 0154-2755 \\ КАЗНИПИМУНАЙГАЗ \\ Республика Казахстан, г. Актау, 35 мкр., 6/1
}

В статье рассматриваются актуальные вопросы выбора наиболее приемлемых методов увеличения нефттеотдачи пластов в условиях осложненности процесса разработки с точки зрения природных и технологических факторов. Автором рассматривается один из наиболее эфрфективных на сегодняшний день методов - полимерное заводнение, которое позволяет не только повысить уровень нефтеотдачи, но и решает ряд комплекс задач по повышению характеристик нефтепродуктов и состояния коллекторов, что особенно важно на месторождениях с преобладанием литологически сложной структуры нефртегазоносных пластов.

Также в статье приводится сопоставительный анализ критериев выбора технологических аспектов организации полимерного заводнения и выбора реагента, которые влияют на экономическую и технологическую эффрективность применения того или иного полимера.

КЛЮЧЕВЫЕ СЛОВА: полимерное заводнение, повышение нефртеотдачи, методы повышения нефтеотдачи, месторождения поздней стадии разработки, фризико-химические методы повышения нефтеотдачи, воздействие на пласт.

\footnotetext{
* Адрес для переписки. E-mail: kali_m@kaznipi.kz
} 


\title{
ИГЕРУДІҢ КЕШ САТЫСЫ ЖАҒДАЙЫНДА ҚАБАТТАРДЫН МҰНАЙБЕРГІШТІГІН АРТТЫРУ ҮШІН ПОЛИМЕРЛІ СУЛАНДЫРУДЫ ҚОЛДАНУ ТИІМДІЛІГІН БАҒАЛАУ
}

М.Е. КАЛИ, экономикадан фрилософияя докторы (PhD), экономикалық зерттеулер бойынша сарапшы, https://orcid.org/ 0000-0002-0154-2755

\author{
ҚАЗМҰНАЙГАЗҒЗЖИ \\ Қазақстан Республикасы, Ақтау қ-сы, 35 мкр., 6/1
}

Мақалада табиғи және технологиялық факторлар тұрғысынан даму процесінің күрделілігі жағдайында мұнай алуды күшейтудің қолайлы әдістерін таңдаудың өзекті мәселелері талқыланады. Автор қазіргі кездегі ең тиімді әдістердің бірі - полимерлі су айдау, бұл мұнай алу деңгейін жоғарылатуға ғана емес, сонымен қатар мұнай өнімдерінің сипаттамалары мен қабаттардың мұнайбергіштігін көтеру бойынша бірқатар міндеттерді шешуді қарастырады, бұл әсіресе мұнай мен газ қоймаларының литологиялық күрделі құрылымы басым кен орындарында маңызды.

Сонымен қатар мақалада, полимерлі су айдаудың технологиялық аспектілерін таңдау критерийлерінің салыстырмалы талдауы мен реагентті таңдау, сондай-ақ нақты полимерді қолданудың экономикалық және технологиялық тиімділігіне әсер ететін негізаі көрсеткіштері көрсетілген.

ТҮЙІн СөзДЕР: полимерлі су айдау, мұнайбергіштікті көтеру, мұнай алудың жетілдірілген әдістері, соңғы сатыдағы кен орындар, мұнай алудағы фризико-химиялық әдістер, қабатқа әсер ету.

\section{ASSESSMENT OF EFFICIENCY OF POLYMER WATERFLOODING FOR INCREASING OIL RECOVERY IN THE CONDITIONS OF THE LATER STAGE OF DEVELOPMENT}

M.E. KALI, PhD in Economics, expert in economic research, https://orcid.org/ 0000-0002-0154-2755

\author{
KAZNIPIMUNAYGAS \\ 6/1, 35 mcr, Aktau, Republic of Kazakhstan
}

The article discusses the relevant issues of choosing the most acceptable methods for enhancing oil recovery, in conditions of the complexity of the development process from the point of view of natural and technological factors. The author considers one of the most effective methods today - polymer waterflooding, which allows not only to increase the level of oil recovery, but also solves a number of tasks to improve the characteristics of oil products and the state of reservoirs, which is especially important in fields with a predominance of lithologically complex structure of oil and gas reservoirs.

KEY WORDS: polymer waterflooding, enhanced oil recovery, enhanced oil recovery methods, late stage fields, physicochemical enhanced oil recovery, reservoir stimulation.

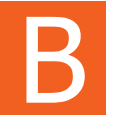

современных условиях, в виду мировых тенденций к исчерпанию ресурсов, добываемых в естественном режиме, когда большинство разрабатываемых месторождений отличает существенная осложенность процесса добычи нефти и газа, эффективность нефтедобывающего предприятия обуславливает правильность выбора тех или иных методов увеличение нефтеотдачи пластов. 
Многие методики увеличения нефтеотдачи пластов уже не одно десятилетие успешно реализуют задачу по предотвращению увеличения темпов обводненности и снижения дебита скважин. Среди множества известных на сегодняшний день и хорошо апробированных методов увеличения нефтеотдачи выделяется полимерное заводнение как мера по воздействию на пласт, дающая дополнительно положительный эффект в тех случаях, когда нефти месторождения отличаются повышенной плотностью, вязкостью, содержанием солеобразующих металлов, а структура коллектора имеет литологическое сложное строение [1].

Стоит отметить, что болышинство находящихся в разработке современных месторождений по всему миру отмечают именно названные выше характеристики. В Республике Казахстан большая часть месторождений характеризуется высокой глубиной залегания, сложными физико-химическими характеристиками, а также сложностью литологического строения пластов. Тем не менее, современные технологии производства полимеров для заводнения позволяют преодолеть природные факторы, осложняющие процесс нефтедобычи и максимизировать объем добываемых углеводородов.

В ряде источников отмечается мнение, что полимерное заводнение является нецелесообразным методом на поздних стадиях разработки месторождения. Тем не менее, данное утверждение справедливо лишь отчасти. Дело в том, что при применении полимерного заводнения критически важным является не только выбор состава и техники закачки агента, но и выбор участка воздействия. В свою очередь, критерии выбора достаточно обширны и включают факторы природного, технического и экономического характера. В конечном счёте, на современном этапе на месторождениях поздней стадии разработки с учётом обширного перечня современных методов увеличения нефтеотдачи, экономический фактор выступает первым и наиболее важным критерием применение того или иного метода извлечения запасов. Тем более, что на современном этапе производители полимеров предлагают широкий диапазон разнообразных по своим физико-химическим свойствам и составу реагентов, соответствующих различным исходным условиям для решения задачи по повышению нефтеотдачи с максимальной эффективностью [2,3].

Кроме того, экономическую привлекательность полимерного заводнения обуславливает относительно низкая себестоимость продукта для закачки и производимых работ.

В мировой практике накоплен достаточно богатый опыт применения полимерного заводнения на месторождениях поздней стадии разработки, и его изучение позволяет утверждать, что правильно выбранный участок и метод применения полимеров, а также использование прогностических моделей на стадиях планирования мероприятия даёт положительный эффект. При этом происходит не только увеличение уровня дебита скважин, но и снижаются темпы роста обводненности, снижаются затраты поддержания искусственного давления на пласт. Также улучшаются физико-химические свойства высоковязких нефтей, предотвращается закупорка коллекторов и влияние осадочных отложений на детали оборудования, что продлевает срок службы последнего и сокращает эксплуатационные затраты [4].

С учетом экономической привлекательности, наличия продолжительного пролонгированного эффекта от воздействия полимеров на факторы снижения себестоимости добычи полимерное заводнение на сегодняшний день вновь является одной из наиболее перспективных методик воздействия на продуктивные пласты с целью повышения 
нефтеотдачи. Мировой опыт применения полимерного заводнения в различных вариациях демонстрирует достаточно высокие результаты при самых разнообразных условиях и осложнениях технологического, физико-химического и литологического характера:

- в отношении сложно структурированных продуктивных горизонтов с множественной перфорацией пластов - месторождение Дацин, Китай;

- в условиях добычи высоковязкой тяжелой нефти - месторождение Агаджари, Иран [5,6].

Рассматриваемое в данной статье месторождение в Мангистауской области полуостров Бузачи представляет собой достаточно интересный объект с позиции изучения анализа эффективности применения полимерного заводнения. Наряду со сложными условиями добычи, месторождение отличает наличие эмпирических данных по применению полимерного заводнения, а также применению сшитых полимерных систем. При этом есть основания дальнейшего неоднократного использования данного метода для повышения эффективности процесса нефтедобычи.

Газонефтяное месторождение разрабатывается с конца семидесятых годов 20-го века. Структуру нефтегазоносных пластов месторождения образуют среднеюрские, триасовые и меловые отложения толщиной в среднем до 2395 метров, при этом глубина продуктивных горизонтов варьируется от 500 до 936 метров. Литологическое строение нефтегазоносных пластов отличает сводовость и тектоническая экранированность. Коллекторы пластов продуктивных горизонтов имеют поровое строение, представленное песчаниками и алевролитами, с показателями открытой пористости от 23\% до 29\% и в целом, с хорошей проницаемостью - от 0,105 до 1,468 мкм². Покрытие коллекторов образовано глинистыми породами толщиной от 4 метров до 53 метров. Особенностью физико-химических свойств нефти месторождения является наличие высоких концентраций ванадия и никеля (преимущественно, ванадиевого типа). Нефть месторождения относится к категории высоковязких (до 19,5), тяжелых (в пределах

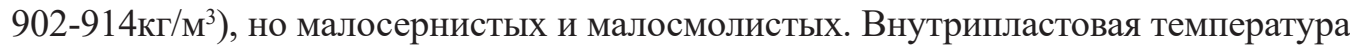
колеблется на различных участках от 39 до $440^{\circ} \mathrm{C}$. Минерализация внутрипластовых вод умеренно высокая- 97,4-170,6 г/л. [7].

Как следует из основных характеристик анализируемого месторождения, его эффективная разработка возможно лишь путем поддержания искусственного воздействия на продуктивные пласты. Природные условия процесса добычи характеризует также и многопластовая структура месторождения практически на всех участках, что делает целесообразным объединение нескольких горизонтов в более крупные эксплуатационные объекты.

Пористость структуры коллекторов и невысокая толщина продуктивных пластов предрасполагает к появлению риска резкого снижения коэффициента вытеснения нефти водой из-за низкой нефтенасыщенности пласта в случае заводнение с используем любых агентов. В первую очередь, это связано с высокой приемистостью пор коллекторов [8].

С учетом повышенной вязкости нефти и довольно высокой минерализации, полимерное заводнение является перспективным методом увеличение нефтеотдачи, которое может быть реализовано с учетом данных специфических условий.

Существенным преимуществом полимерного заводнения, наряду с относительно низкой себестоимостью и относительной невысокой ресурсоемкостью, является воз- 
можность внедрения в адаптивную систему, которая на данный момент применяется на месторождении.

За всю историю разработки на месторождении неоднократно применялись различные методы полимерного заводнения для увеличения нефтеотдачи, начиная с 1981 года и по настоящее время. Результативность примененных методов варьировалась от 50 до 158 тонн добытой нефти на 1 тонну затраченного ПАА [9].

Несмотря на имеющийся обширный опыт применения методов полимерного заводнения, в каждой отдельно взятой ситуации необходимо отталкиваться от целесообразности применения данного метода на данном участке с учётом всех факторов и рисков.

Ведущую группу применяемых для заводнения полимеров составляют низкомолекулярные акриламиды в виду их способности увеличивать вязкость воды в гидролизованным состоянии, а также относительно низкой себестоимости реагента, высокой стойкости к действию бактерий и способности создавать постоянное уменьшение проницаемости, которая является важным фактором экономической эффективности в условиях добычи высоковязкой тяжелой нефти [10].

Фактором, сужающим круг потенциально пригодных для применения полимерных продуктов, является требуемая концентрация не ниже 90\%, следовательно, целесообразно рассматривать порошкообразные формы ПАА. Данные условия продиктованы требуемой достаточно высокой загущающей способностью раствора [10, с.5].

ПАА с требуемыми характеристиками широко распространены в линейках производителей Франции, Южной Кореи, Китая, России, США и др.

Выбор в пользу полиакриламидов сделан с учетом особенностей, общих для всех залежей месторождения, но выбор той или иной марки, а также состава реагента и варианта его закачки целесообразно рассматривать применительно к отдельно взятому участку [11].

На приведенном в пример месторождении ведется разработка по нескольким опытным участкам, отличающихся разнородностью характеристик нефтегазоносных пластов. Поэтому для расчета экономической эффективности в данной статье целесообразно привести расчеты по одному из опытных участков [9, с.19-25].

Ниже представлены данные, отражающие планируемые мероприятия по полимерному заводнению участка №1. Реализация метода полимерного заводнения на данном участке не требует существенных дополнительных затрат на улучшение технического состояния нагнетательного фонда, так как с 2014 года и на текущий момент уже реализуется опытно-промышленное полимерное заводнение и заполнено 6,2\% порового пространства (таблища 1). Хронологические рамки расчета соответствуют заявленной длительности мероприятия - с января 2019 по июль 2028 год. Выкопировка карты текущих отборов планируемого участка представлена на рисунке 1.

Анализ соответствия, приведенный в данной таблице, указывает на возможность применения полимерного заводнения с использованием полиакриламида.

Среди продуктовой линейки при выборе следует отталкиваться от требуемых свойств, применительно к каждому отдельному участку.

Исходя из свойств нефтегазоносных пластов анализируемого участка, характеризующихся высокой степенью обводненности, наличием минерализации и риска адсорбции, необходимо применение полимерного реагента, отличающегося следующими требуемыми критериями: 


\section{ЭКОНОМИКА}

Таблица 1 - Анализ возможности применения полимерного заводнения с использованием полиакриламида на участке №1 анализируемого месторождения

\begin{tabular}{|c|c|c|}
\hline Критерий & Значение по участку & $\begin{array}{c}\text { Значение, } \\
\text { предпочтительное для П3 }\end{array}$ \\
\hline Приемистость, м³ /сут. & 224 (хорошая) & Хорошая \\
\hline Пластовая температура, 을 & 40 & До 120 \\
\hline Вязкость нефти, сП & 23,3 & От 10 сП до 10000 сП \\
\hline Проницаемость, Д. & 0,423 & От 50 мД до 10 Д \\
\hline Пористость, д.ед. & 0,28 & --------- \\
\hline Литологический состав & $\begin{array}{c}\text { Песчаник и алевролиты с } \\
\text { глинистым покрытием }\end{array}$ & Песчаник \\
\hline Нефтенасыщенность & 0,66 & $>20 \%$ \\
\hline Плотность нефти, API & 25 & $>15$ \\
\hline Пористость, д.ед. & $\begin{array}{l}\text { 0,27- Большая емкость } \\
\text { коллектора }\end{array}$ & ------- \\
\hline Обводненность, \% & 89,6 & $\begin{array}{l}\text { Высокая степень } \\
\text { обводненности }\end{array}$ \\
\hline
\end{tabular}

* Примечание: составлено автором на основании источника №9, с.19-25, №12, с.5

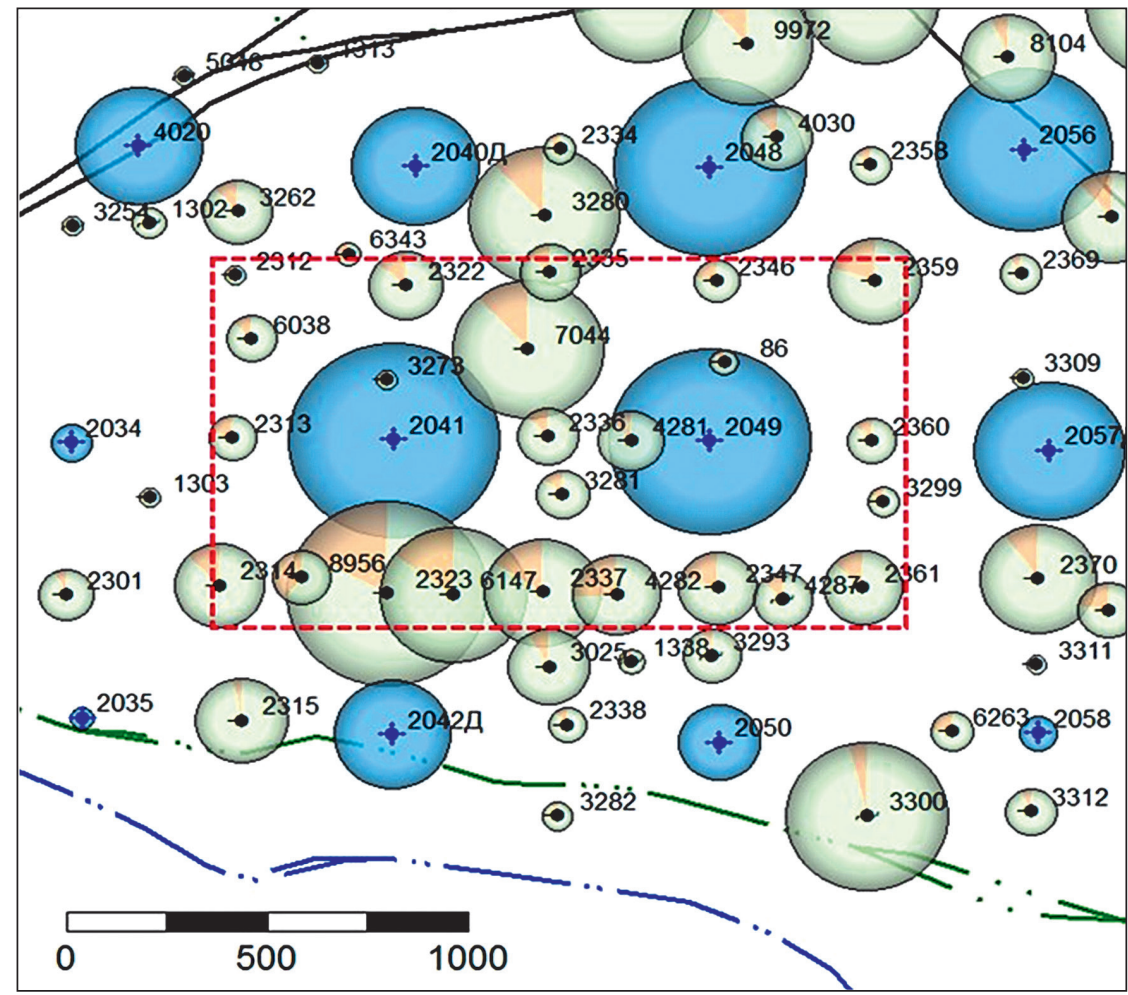

Рисунок 1 - Участок №1. Выкопировка с карты текущих отборов 
1. Хорошая загущающая способность применительно к данному типу нефти при вязкости нефти в 23,3cП;

2. Высокая растворимость, и защита от химической диструкции;

3. Биологическая устойчивость;

4. Пониженный риск гелеобразования и осаждения частиц.

Следовательно, оптимальным вариантом является акриламиды, произведенные путем сополимеризации, так как имеют хорошую растворимость, наименьшую склонность к гелеобразованию и осаждению в виду узкого распределения аннионности, приобретаемой в процессе изготовления данным способом.

Также из-за относительно высокой минерализации, желательно наличие добавок, снижающих риск образования свободных радикалов. Стоит отметить, что с точки зрения снижения издержек предпочтителен продукт уже имеющий требуемые защитные свойства, так как изготовление реагента под заказ неизбежно отразится на уровне затрат по увеличению нефтеотдачи полимерным заводнением. С учетом данных требований, полимер должен обладать низкой или средней молекулярной массой [13].

Ниже представлена аналитическая таблица выбора реагента с требуемыми свойствами (таблицуа 2).

\section{Таблица 2 - Анализ линейки реагентов для закачки на участке №1 анализируемого месторождения}

\begin{tabular}{|c|c|c|c|}
\hline Продукция & Анионность & $\begin{array}{l}\text { Молекулярная } \\
\text { масса }\end{array}$ & $\begin{array}{l}\text { Чувствительность } \\
\text { к минерализации }\end{array}$ \\
\hline $\begin{array}{l}\text { Акрилами-акрилатный } \\
\text { сополимер }\end{array}$ & $\begin{array}{c}\text { От средней до } \\
\text { высокой }\end{array}$ & Крайне низкая & Средняя \\
\hline $\begin{array}{l}\text { Сополимеры акриламидо- } \\
\text { третбутиловой сульфокислоты } \\
\text { и акриламида }\end{array}$ & Очень низкая & Низкая & Слабая \\
\hline $\begin{array}{l}\text { Сополимеры акриламида/ } \\
\text { акриламидо-третбутиловой } \\
\text { сульфокислоты/акриловой } \\
\text { кислоты }\end{array}$ & $\begin{array}{c}\text { От средней до } \\
\text { высокой }\end{array}$ & $\begin{array}{l}\text { От средней до } \\
\text { высокой }\end{array}$ & Слабая \\
\hline $\begin{array}{l}\text { Терполимеры акриламида, } \\
\text { акриламидо-третбутиловой } \\
\text { сульфокислоты и } \\
\text { N-винилпирролидона }\end{array}$ & Средняя & Низкая & Крайне слабая \\
\hline Ассоциированные полимеры & Низкая & Низкая & Крайне слабая \\
\hline
\end{tabular}

* Примечание: составлено автором на основании источника №13

Как следует из результатов анализа, наилучшими качествами обладают ассоциированные сополимеры.

Далее приведено обоснование экономической эффективности опытно-промышленных работ (далее - ОПР) по испытанию технологии полимерного заводнения на участке №1 месторождения.

Для экономической оценки были приняты технологические прогнозные показатели по дополнительной добыче нефти, по расходу сухого полимера, а также его стоимость, при этом, другие параметры для оценки (цены реализации нефти, доля 
экспорта/внутреннего рынка, налогообложение, тариф на транспортировку и др.) за расчетный период использовались по прогнозным данным.

Срок реализации проекта как один из показателей экономической эффективности проекта по участку №1 рассчитывался за прогнозный период добычи нефти от проведения мероприятий - 2019-2028 годы.

В расчетах за основные источники доходов приняты поступления от реализации дополнительной добычи нефти. Цена реализации нефти на внешний рынок за проектный период принята в соответствии с макропрогнозными данными нефтегазодобывающего сектора: за 2019-2020 гг. - 55 \$/баррель, 2021-2026 гг. - 60 \$/баррель, 2027-2028 гг. 65 \$/баррель. Также стоит отметить, что в расчетах приняты прогнозные цены реализации нефти на внутренний рынок. Цены на внутренний рынок за расчетный срок колеблются на уровне 87 \$ тонна - 159 \$/тонна.

Моделирование эксплуатационных затрат на опытном участке №1 месторождения проводилось за проектный период в соответствии с основными технологическими показателями, рассчитанными исходя из технологии и техники добычи, подготовки и транспорта нефти, налоговых ставок и способов расчета амортизационных начислений.

В состав эксплуатационных затрат были включены затраты, связанные с добычей дополнительного объема нефти, транспортировкой нефти, амортизационные отчисления и накладные расходы, налоги и отчисления в бюджет.

Сумма амортизационных отчислений, включаемых в себестоимость, была определена линейным методом, т.е. посредством списания стоимости основных фондов одинаковыми пропорциональными частями на протяжении их эксплуатационного периода от первоначальной стоимости основных средств. Срок эксплуатационного периода составил 10 лет.

Также было учтено, что при реализации проекта предполагаются дополнительные инвестиционные затраты, связанные с закачкой агента, включающие в себя услуги подрядной организации, а также затраты на покупку полимера.

Для расчета нормативов эксплуатационных затрат в учет были приняты исходные фактические и прогнозные данные Недропользователя за расчетный период.

Капитальные вложения на проведение ОПР по применению полимерного заводнения на опытном участке приняты в расчете по предварительным сметным расчетам и составляют 1154 тыс. \$.

Дисконтирование проводилось исходя из теории временной стоимости денег для получения суммы потоков платежей, приведенных к настоящему моменту времени. Для определения дисконтированных потоков приняты ставки дисконтирования WACC на уровне $11,5 \%$.

Технико-экономическая оценка и сравнение результатов ОПР проводились по основным критериям доходности, к которым относятся потоки денежной наличности (CASH FLOW), чистая приведенная стоимость (NPV), внутренняя норма доходности (IRR), срок окупаемости (PP, DPP) и индекс доходности проекта (PI).

Итак, в результате проведенных расчетов были определены выручка от реализации продукции, эксплуатационные затраты на дополнительную добычу нефти и газа, инвестиций в капитальное строительство, чистая прибыль недропользователя, а также налоги и отчисления в бюджет.

Расчет экономической эффективности и итоговые интегральные показатели внедрения технологии полимерного заводнения на участке №1 представлены в таблицах 5 и 6. 


\begin{tabular}{|c|c|c|c|c|c|c|c|c|c|c|c|c|c|c|c|c|c|c|c|c|c|c|c|c|c|c|}
\hline 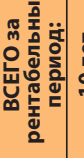 & $\begin{array}{l}5 \\
\stackrel{5}{5} \\
\stackrel{0}{0}\end{array}$ & \begin{tabular}{l}
0 \\
0 \\
0 \\
0 \\
\hdashline
\end{tabular} & 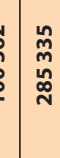 & $\begin{array}{c}n \\
\infty \\
\infty \\
\infty \\
\infty\end{array}$ & & 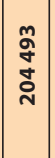 & $\begin{array}{l}\text { :ి } \\
0 \\
\tilde{m} \\
\text { N }\end{array}$ & & & & $\begin{array}{l}\stackrel{0}{0} \\
\stackrel{n}{=} \\
\end{array}$ & & & & $\begin{array}{l}\bar{\sigma} \\
\hat{\sigma}\end{array}$ & 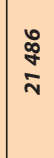 & $\mid \begin{array}{c}\infty \\
\stackrel{2}{0} \\
i\end{array}$ & 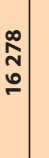 & $\left|\begin{array}{l}m \\
i \\
m\end{array}\right|$ & $\nwarrow \bar{N}$ & $\bar{N}$ & 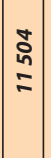 & $\left|\begin{array}{c}-\infty \\
0 \\
\infty\end{array}\right|$ & $\left|\begin{array}{c}m \\
\mathfrak{N} \\
\mathbf{v}\end{array}\right|$ & & \\
\hline \multirow{10}{*}{ 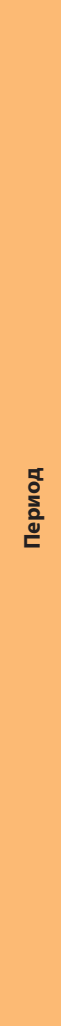 } & a & $\frac{\infty}{b}$ & 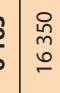 & m & $\frac{\circ}{\stackrel{\circ}{\Gamma}}$ & $\begin{array}{c}\bar{\sigma} \\
\hat{n} \\
\overline{=}\end{array}$ & $\begin{array}{l}\hat{n} \\
\hat{n} \\
=\end{array}$ & ถి & 号 & $\begin{array}{l}0 \\
\stackrel{m}{0}\end{array}$ & กิ & ๙ें & 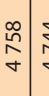 & $\begin{array}{lll}\text { ty } \\
\sigma\end{array}$ & 总 & $\stackrel{\widetilde{N}}{\sim}$ & ถે & 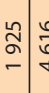 & $\vec{y}$ & $m \stackrel{n}{m}$ & $? \stackrel{2}{-}$ & $\stackrel{\infty}{N}$ & 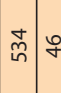 & 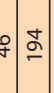 & $\bar{\sigma}$ & \\
\hline & 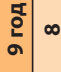 & $\frac{n}{a}$ & $\stackrel{\sim}{n}$ & $\underset{\infty}{\mathbb{N}}$ & 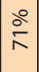 & $=\overbrace{7}^{\infty}$ & $=太$ & ถ & $\stackrel{8}{\stackrel{8}{\sigma}}$ & $\stackrel{\circ}{\mathrm{m}}$ & $\begin{array}{l}\stackrel{0}{\circ} \\
\stackrel{-}{\circ}\end{array}$ & ڤे & 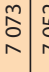 & $\begin{array}{lll} \\
\end{array}$ & $\begin{array}{l}n \\
\infty \\
0 \\
0\end{array}$ & 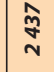 & in & 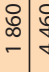 & $\vec{y}$ & $\stackrel{\infty}{i} \bar{\sim}$ & $i \bar{N}$ & $\begin{array}{l}\text { ‡ } \\
\vdots \\
-2\end{array}$ & 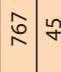 & $f)$ & 웅 & \\
\hline & 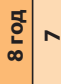 & 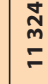 & 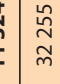 & $\begin{array}{l}\text { ळे } \\
\text { ळ̆ }\end{array}$ & $\begin{array}{l}\stackrel{\circ}{\wedge} \\
\stackrel{2}{n}\end{array}$ & 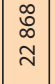 & 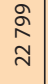 & 8 & 苞 & : & $\stackrel{m}{\xi}$ & ふें & 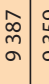 & 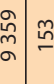 & مू & $\stackrel{\hat{\gamma}}{\sim}$ & $\hat{\mathrm{n}}$ & \begin{tabular}{c|c}
$:$ & \\
$\infty$ \\
$\infty$
\end{tabular} & $\hat{y}$ & $\curvearrowright \curvearrowright$ & $\grave{\lambda}$ & $\mid \begin{array}{l}0 \\
m \\
-\end{array}$ & ¿ & 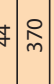 & f & \\
\hline & 。 & ڤ్ & 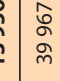 & $\stackrel{n}{N}$ & 品 & $\begin{array}{c}\stackrel{m}{\sim} \\
\stackrel{D}{\sim}\end{array}$ & $\begin{array}{l}\stackrel{\infty}{\stackrel{\infty}{n}} \\
\stackrel{\infty}{\sim}\end{array}$ & 8 & 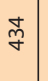 & : & $\underset{\Sigma}{\Sigma}$ & ڤे & 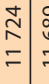 & \begin{tabular}{c|c}
$\stackrel{g}{o}$ \\
\hdashline \\
$=$ & $g$ \\
\end{tabular} & $\frac{5}{\sigma}$ & 하 & $\hat{i n}$ & 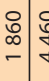 & $\grave{f}$ & ஃ & $\tilde{m}$ & \begin{tabular}{l}
0 \\
$:$ \\
\hdashline
\end{tabular} & 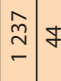 & $\bar{y} \bar{\gamma}$ & $\hat{m}$ & \\
\hline & \begin{tabular}{l|l}
$\mathbf{0}$ \\
$\vdots$ \\
0
\end{tabular} & \begin{tabular}{l}
$\mathcal{N}$ \\
J \\
\multirow{J}{*}{}
\end{tabular} & 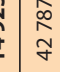 & م̂ & $\stackrel{\circ}{\stackrel{0}{人}}$ & $\mid \begin{array}{l}0 \\
\tilde{N} \\
0 \\
m\end{array}$ & 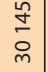 & 8 & $\stackrel{\ddagger}{\dddot{m}}$ & : & 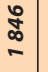 & ৯े & 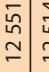 & 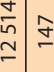 & ఫิ & $\stackrel{\hat{\gamma}}{\sim}$ & $\hat{i n}$ & \begin{tabular}{c|c}
$:$ & $\vdots$ \\
\hdashline & $\vdots$
\end{tabular} & $\grave{b}$ & $\stackrel{m}{=} \stackrel{m}{m}$ & $m$ & 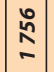 & 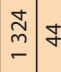 & $\dot{y}$ & $\stackrel{+}{m}$ & \\
\hline & $\begin{array}{l}\text { to } \\
\text { in }\end{array}$ & $\begin{array}{c}\text { Oे } \\
m \\
m\end{array}$ & 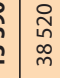 & 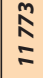 & $\stackrel{\circ}{\stackrel{2}{R}}$ & $\begin{array}{l}\bar{\sim} \\
\underset{\sim}{\sim}\end{array}$ & 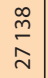 & 8 & 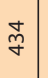 & : & $\hat{\vdots}$ & ڤे & $\begin{array}{l}\stackrel{2}{\hat{े}} \\
=\end{array}$ & 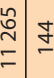 & {$\left[\begin{array}{l}n \\
0 \\
\infty \\
\infty\end{array}\right.$} & $\stackrel{\widehat{m}}{\text { సे }}$ & $\hat{\text { in }}$ & \begin{tabular}{l|l}
$\circ$ & \\
$\infty$ & \\
- &
\end{tabular} & $\bar{\gamma}$ & ๙ૂ গి & iి & 会 & $\begin{array}{l}m \\
\stackrel{n}{=} \\
=\end{array}$ & f & $\stackrel{m}{m}$ & \\
\hline & 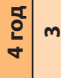 & $\begin{array}{l}\text { ò } \\
\dot{I}\end{array}$ & $\begin{array}{l}\tilde{n} \\
\vdots \\
\vdots \\
o \\
\vdots\end{array}$ & 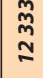 & $\frac{\circ}{\curvearrowright}$ & \begin{tabular}{|c|c}
$\infty$ \\
$i$ \\
$\infty$ \\
$\sim$ \\
$\sim$
\end{tabular} & 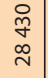 & 8 & भु & 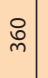 & $\begin{array}{l}8 \\
6 \\
-\end{array}$ & ふे & $\begin{array}{ll}\infty & \\
\infty & \\
\vdots & \vdots\end{array}$ & 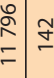 & m & ని & $\hat{i n}$ & 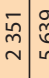 & $\frac{\widehat{y}}{\bar{\sigma}}$ & సิ ภิ & i & 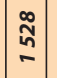 & 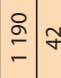 & $y$ & సิ & \\
\hline & $\stackrel{\substack{0 \\
m}}{N}$ & $\begin{array}{l}\text { : } \\
\text { o }\end{array}$ & 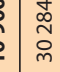 & గิ & 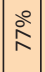 & $\mid \begin{array}{l}0 \\
\stackrel{0}{0} \\
\sim \\
\sim\end{array}$ & $\stackrel{\substack{\infty \\
\tilde{N}}}{\stackrel{\sim}{\sim}}$ & 8 & $\stackrel{+}{m}$ & 유. & \& & ळे & 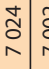 & 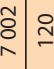 & 离 & : & $\hat{i n}$ & \begin{tabular}{l|c}
$\bar{\sigma}$ \\
$\stackrel{n}{n}$
\end{tabular} & $\hat{m}$ & $\begin{array}{lll}\infty & \bar{N}\end{array}$ & $i \bar{v}$ & 莣 & $\stackrel{\nabla}{0}$ & $y \stackrel{g}{g}$ & $\stackrel{\infty}{\sim}$ & \\
\hline & $\stackrel{\substack{\mathrm{L} \\
\text { N }}}{-}-$ & $\begin{array}{l}\text { å } \\
\text { in }\end{array}$ & 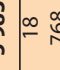 & $\stackrel{m}{g}$ & 号 & $\pm \stackrel{\infty}{\alpha}$ & $m=\frac{\Delta}{\infty}$ & & $\stackrel{\infty}{\circ}$ & $\stackrel{\circ}{\circ}$ & ఫे & ڤેं & 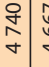 & 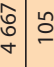 & $\int_{\substack{0 \\
0}}^{0}$ & ồ & $\frac{\sigma}{\gamma}$ & 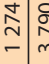 & $\stackrel{0}{0}$ & in $=$ & $=$ & 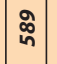 & \begin{tabular}{l|l}
$\stackrel{n}{\hat{f}}$ & $\dot{m}$ \\
$m$
\end{tabular} & 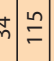 & $\stackrel{n}{\sim}$ & \\
\hline & 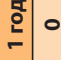 & 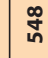 & 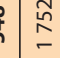 & นิ & 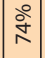 & 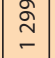 & $\stackrel{\bar{\infty}}{\stackrel{D}{\sim}}$ & in & $\stackrel{\infty}{m}$ & : & ले & ఏें & $\stackrel{m}{\mathscr{f}}$ & fo & $\tilde{\infty}_{\infty}^{\circ}$ & สิ & 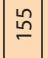 & $\hat{\tilde{m}}$ & $\equiv$ & $\div N$ & $\sim$ & in & $f \stackrel{\circ}{\circ}$ & $\stackrel{n}{n} \wedge$ & 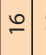 & 2 \\
\hline ్ㅡㄴ & u & 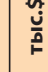 & 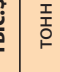 & है & & 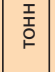 & 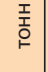 & $=$ & 票 & 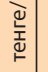 & है & & 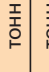 & 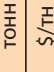 & $\frac{\tilde{v}}{\hat{n}}$ & है & 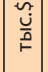 & 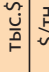 & I & 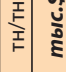 & 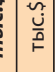 & 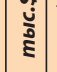 & 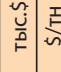 & 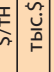 & $\mid \begin{array}{l}I \\
w\end{array}$ & है \\
\hline 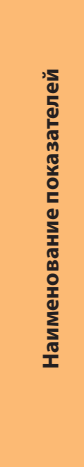 & $\infty$ & 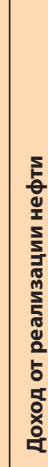 & 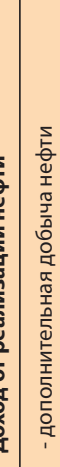 & 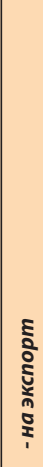 & 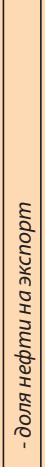 & 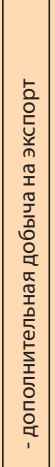 & 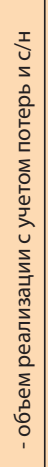 & 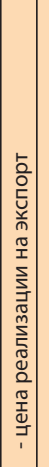 & 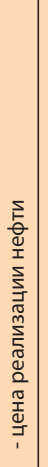 & 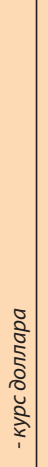 & 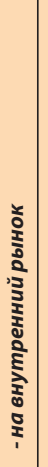 & 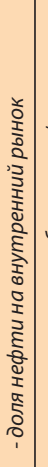 & 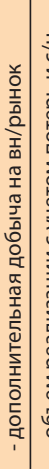 & 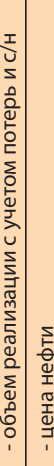 & 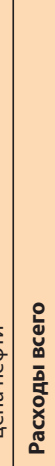 & 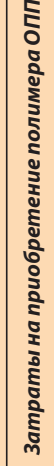 & 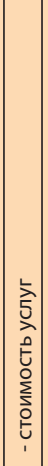 & 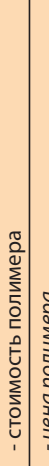 & 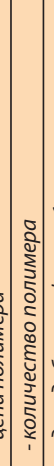 & 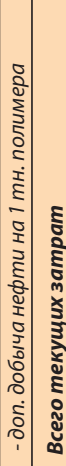 & 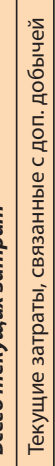 & 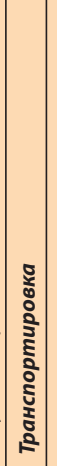 & 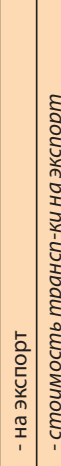 & 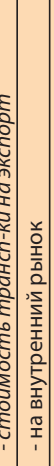 & 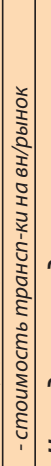 & 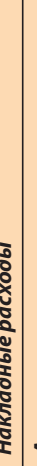 \\
\hline $2 \frac{91}{2}$ & $\ll$ & - & & - & & & & & & & 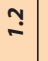 & & & & $N$ & $\bar{i}$ & & & & $\underset{\sim}{ }$ & $\begin{array}{l}\bar{i} \\
\bar{N}\end{array}$ & $\mathbf{N}$ & & & & $\dot{j}$ \\
\hline
\end{tabular}




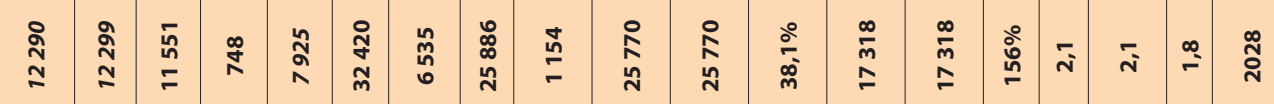

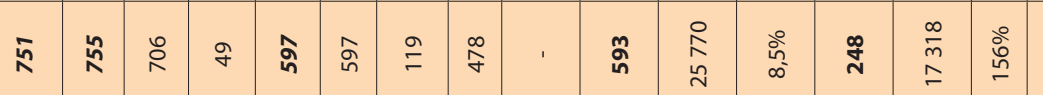

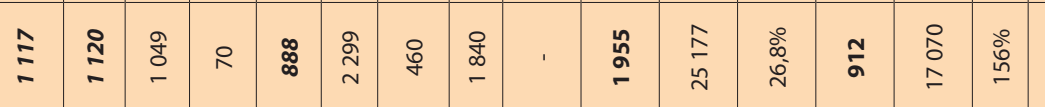

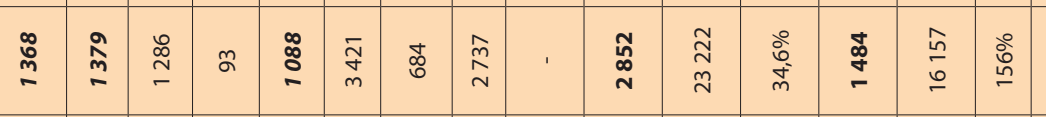

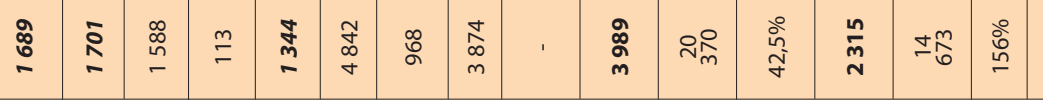

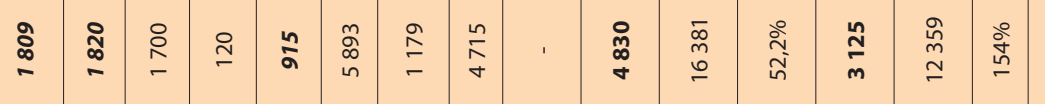

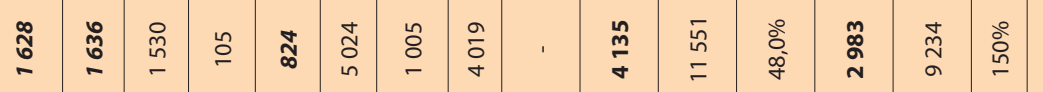

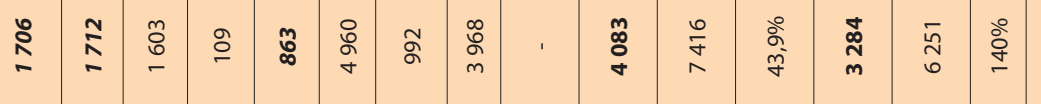

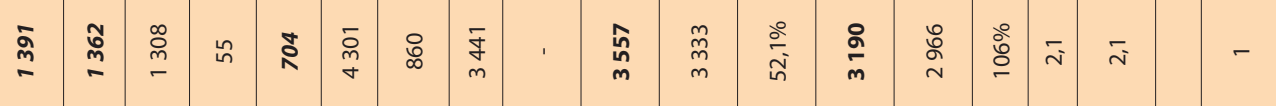

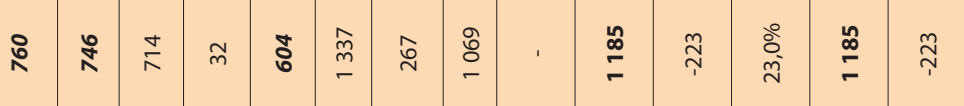

尺

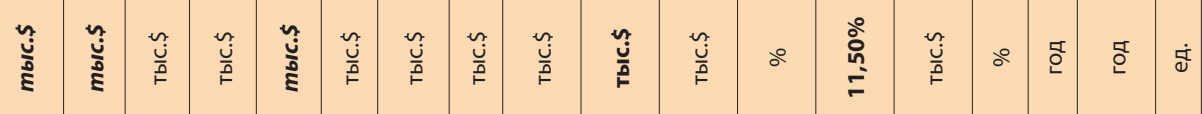

\begin{tabular}{|c|c|c|c|c|c|c|c|c|c|c|c|c|c|c|c|c|c|c|}
\hline 点 & 彥 & 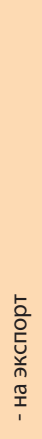 & 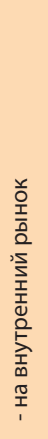 & 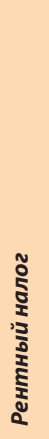 & 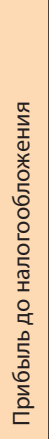 & 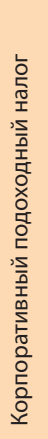 & 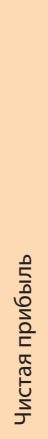 & 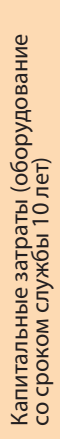 & 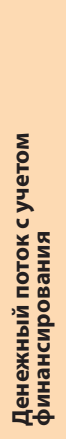 & 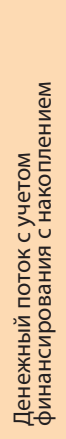 & 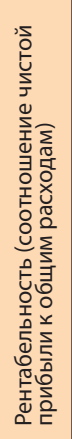 & 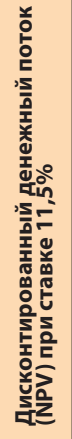 & 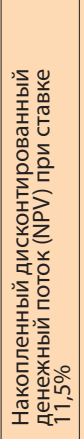 & 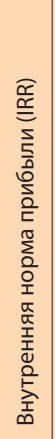 & 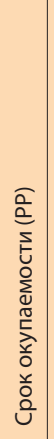 & 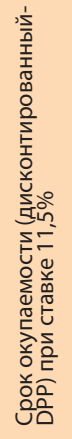 & 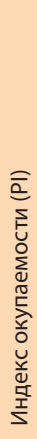 & 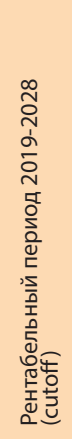 \\
\hline$\stackrel{\circ}{\mathfrak{i}}$ & $\hat{\boldsymbol{i}}$ & & & $\stackrel{\infty}{i}$ & $m$ & $\nabla$ & in & 0 & $\wedge$ & $\infty$ & $a$ & $\stackrel{\circ}{\circ}$ & $=$ & $\simeq$ & $\stackrel{m}{-}$ & $\tau$ & $\stackrel{n}{\llcorner}$ & - \\
\hline
\end{tabular}


Таблица 6 - Итоговые интегральные показатели экономической эфффективности

\begin{tabular}{|c|l|c|c|}
\hline $\begin{array}{c}|c| \\
\text { № }\end{array}$ & \multicolumn{1}{|c|}{ Наименование показателей } & ЕИ & $\begin{array}{c}\text { Значение } \\
\text { показателей }\end{array}$ \\
\hline 1 & Расчетный период & годы & 10 лет \\
\hline 2 & Рентабельный период & годы & 10 лет \\
\hline 3 & Дополнительная добыча нефти & тонн & 285335 \\
\hline 4 & Расходы полимера & тонн & 3713 \\
\hline 5 & Выручка от продажи нефти & млн. \$ & 100,4 \\
\hline 6 & Эксплуатационные затраты & млн. \$ & 67,9 \\
\hline 7 & Капитальные вложения & млн. \$ & 1,2 \\
\hline 8 & Чистая прибыль & млн. \$ & 25,9 \\
\hline 9 & Дисконтированный денежный поток (NPV) при ставке 11,5\% & млн. \$ & 17,3 \\
\hline 10 & Внутренняя норма прибыли (IRR) & $\%$ & $156 \%$ \\
\hline 11 & Срок окупаемости (дисконтированный-DPP) при ставке 11,5\% & лет & 2,1 \\
\hline 12 & Индекс окупаемости (РI) & д.е. & 1,8 \\
\hline
\end{tabular}

Приведенные технико-экономические результаты за рентабельный период свидетельствуют, что внедрение технологии полимерного заводнения с использованием выбранного реагента на участке №1 является экономически эффективным.

При принятых условиях и допущениях по проекту, по итогам проведенных экономических расчетов от внедрения технологии полимерного заводнения на участке Запад за весь рентабельный период получены следующие ожидаемые результаты:

- капитальные вложения -1,2 млн.\$;

- доходы - 100,4 млн.\$;

- расходы - 67,9 млн.\$;

- чистая прибыль - 25,9 млн.\$;

- NPV при ставке 11,5\% - 17,3 млн.\$;

- внутренняя норма прибыли (IRR) - 156\%;

- срок окупаемости проекта - 2,1 года;

- индекс окупаемости (PI) - 1,8 д.е.

В результате расчетов выявлено, что полимерное заводнение с выбранным реагентом является экономически целесообразным и рентабельным. Удельная эффективность применения метода составит 285335 тонн добытой нефти на 3713 тонн затраченного полимера.

Таким образом, на примере одного из участков месторождения Мангистауской области, которое отличает поздняя стадия разработки, осложняющаяся литологическими условиями и физико-химическими свойствами нефти, доказано, что полимерное заводнение представляет одно из перспективных направлений применения химических методов повышения нефтеотдачи пластов. На сегодняшний день возможности полимерного заводнения существенно расширены, благодаря наличию реагентов с адаптированными под условия конкретного проекта свойствами еще на 
этапе производства. Соответственно, перспективы применения одного из наиболее апробированных методы повышения нефтеотдачи пластов на данный период и в ближайшем будущем позволяют с уверенностью говорит о дальнейшем совершенствовании данной технологии и расширении возможностей ее применения.

\section{ЛИТЕРАТУРА}

1 Яковенко А.А., Пруцакова С.А., Кучеренко С.В. Проблемы и перспективы современного развития нефтегазовой промышленности// Булатовские чтения: сборник статей. - Донской государственный технический университет. -2018. - С.374-376 [YAkovenko A.A., Prucakova S.A., Kucherenko S.V. Problemy i perspektivy sovremennogo razvitiya neftegazovoj promyshlennosti// Bulatovskie chteniya: sbornik statej. - Donskoj gosudarstvennyj tekhnicheskij universitet. -2018. - S.374-376]

2 Кастро Р., Перез Р., Майя Г. Применение полимерного заводнения для увеличения коэффрициента извлечения нефти//Казань.: Георесурсы, №4. -2016. -С.271-280 [Kastro R., Perez R., Majya G. Primenenie polimernogo zavodneniya dlya uvelicheniya koefficienta izvlecheniya nefti//Kazan'.: Georesursy, №4. -2016. -S.271-280]

3 Тома А., Саюк Б., Абиров Ж., Мазбаев Е. Полимерное заводнение для увеличения нефтеотдачи на месторождениях легкой и тяжелой нефти// Территория Нефтегаз, №7- М.: Камелот Паблишинг. -2017. -c. 58-68 [Toma A., Sayuk B., Abirov ZH., Mazbaev E. Polimernoe zavodnenie dlya uvelicheniya nefteotdachi na mestorozhdeniyah legkoj i tyazheloj nefti// Territoriya Neftegaz, №7- M.: Kamelot Pablishing. -2017. -s. 58-68]

4 Лысенко В. Д., Грайфер В. И. Инновационная система разработки нефтяных месторождений. - М.: ООО «Недра-БизнесЦентр». -2000. - C.516 [Lysenko V. D., Grajfer V. I. Innovacionnaya sistema razrabotki neftyanyh mestorozhdenij. - M.: OOO «NedraBiznesCentr». -2000. - C.516]

5 Х. Чжун, Ю. Ли, В. Чжан, Х. Инь, Дж. Лу, Д. Го «Микропоточный механизм вытеснения масла за счет вязкоупругого гидрофобного связывания водорастворимых полимеров в увеличении нефтеотдачи» // Полимеры. - 2018. - T. 10, № 628. DOI: 10.3390 / polym10060628 [H. CHzhun, YU. Li, V. CHzhan, H. In', Dzh. Lu, D. Go «Mikropotochnyj mekhanizm vytesneniya masla za schet vyazkouprugogo gidrofobnogo svyazyvaniya vodorastvorimyh polimerov v uvelichenii nefteotdachi» // Polimery. - 2018. - T. 10, № 628. DOI: 10.3390 / polym10060628]

6 Ш. Лян, Ю. Лю, Ш. Ху, А. Шен, К. Ю, Янь Х., Бай М. «Экспериментальное исследование физической производительности и текучести декорированных полиакриламид для увеличения нефтеотдачи» // Энергия. - 2019. - T. 12, № 562. DOI: 10.3390 / en12030562 [SH. Lyan, YU. Lyu, SH. Hu, A. SHen, K. YU, YAn' H., Baj M. «Eksperimental'noe issledovanie fizicheskoj proizvoditel'nosti i tekuchesti dekorirovannyh poliakrilamid dlya uvelicheniya nefteotdachi» // Energiya. - 2019. - T. 12, № 562. DOI: 10.3390 / en12030562];

7 Гусманова А.Г., Жолбасарова А.Т. Геологическое строение и основные характеристики нефтегазоносных горизонтов месторождений Мангистайской области// Вестник Национальной Академии наук Республики Казахстан., №6. -2007. - С.48-50 [Gusmanova A.G., ZHolbasarova A.T. Geologicheskoe stroenie i osnovnye harakteristiki neftegazonosnyh gorizontov mestorozhdenij Mangistajskoj oblasti//Vestnik Nacional'noj Akademii nauk Respubliki Kazahstan., №6. -2007. - S.48-50];

8 Абиров Р.Ж., Мухамедова А.Г., Панабеккызы Б. Промышленное внедрение полимерного заводнения на месторождении южно-тургайского бассейна//Нефтепромысловое дело, №5. -2016. - с. 15-19 [Abirov R.ZH., Muhamedova A.G., Panabekkyzy 
B. Promyshlennoe vnedrenie polimernogo zavodneniya na mestorozhdenii yuzhnoturgajskogo bassejna//Neftepromyslovoe delo, №5. -2016. - s. 15-19]

9 Аналитический отчет по примененным методам полимерного заводнения на участках месторождения Мангистауской области. - КазНИПИмунайгаз. -2017. -35 с. [Analiticheskij otchet po primenennym metodam polimernogo zavodneniya na uchastkah mestorozhdeniya Mangistauskoj oblasti. - KazNIPImunajgaz. -2017. -35 s.]

10 Основы нефтегазопромыслового дела. Учебное пособие. Авторы В. Д. Гребнев, Д. А. Мартюшев Г. П. Хижняк: Перм. нац. иссл. полит. ун-т. Пермь.-2013. -185 с. [Osnovy neftegazopromyslovogo dela. Uchebnoe posobie. Avtory V. D. Grebnev, D. A. Martyushev G. P. Hizhnyak: Perm. nac. issl. polit. un-t. Perm'.-2013. -185 s.]

11 Мордвинов В.А., Поплыгин В.В., Поплыгина И.С. Варианты полимерного заводнения залежи с высоковязкой нефтью//Вестник ПНИПУ: Геология. Нефтегазовое и горное дело, №14. -2015. - С. 39-51 [Mordvinov V.A., Poplygin V.V., Poplygina I.S. Varianty polimernogo zavodneniya zalezhi s vysokovyazkoj neft'yu//Vestnik PNIPU: Geologiya. Neftegazovoe i gornoe delo, №14. -2015. - s. 39-51]

12 Повышение эффективности полимерного заводнения. 30 лет опыта в области технологий повышения нефтеотдачи пластов. - SNF Floerger. -25 c. [Povyshenie effektivnosti polimernogo zavodneniya. 30 let opyta $v$ oblasti tekhnologij povysheniya nefteotdachi plastov. - SNF Floerger. -25 s.]

13 Кнунянц И.Л. Краткая химическая энциклопедия. Том 2. -М.: Книга по требованию. -2013. - 658 c. [Knunyanc I.L. Kratkaya himicheskaya enciklopediya. Tom 2. -M.: Kniga po trebovaniyu. -2013. - 658 s.] 